\title{
Workplace Safety Concerns among Co-workers of Responder Returning from Ebola-Affected Country
}

\section{Benjamin P. Chan, Elizabeth R. Daly, Elizabeth A. Talbot}

We surveyed public health co-workers regarding attitudes toward a physician who returned to New Hampshire after volunteering in the West African Ebola outbreak. An unexpectedly large $(18.0 \%)$ proportion of staff expressed discomfort with the Ebola responder returning to work. Employers should take proactive steps to address employee fears and concerns.

$\mathrm{T}$ he largest Zaire ebolavirus epidemic reported began in West Africa in December 2013 (1) and spread to at least 10 countries, resulting in $>27,000$ suspected, probable, or confirmed cases of Ebola virus disease (EVD) as of June 2015 (2). Arrival of the first case of EVD in the United States resulted in intense public fear and concern, exacerbated by continuous news coverage and misinformation (3). A New Hampshire physician, who worked at the New Hampshire Division of Public Health Services (DPHS), volunteered in West Africa; she provided EVD case management training for health care workers in Ebola treatment centers in Sierra Leone but did not provide direct patient care. When she returned to New Hampshire, in accordance with guidelines of the Centers for Disease Control and Prevention and DPHS, she was considered low risk for EVD development and instructed to self-monitor with daily phone checks from DPHS; home quarantine and movement restrictions were not required $(4,5)$. Given the heightened fear surrounding Ebola, we conducted an assessment of attitudes and intended practices in presumably EVD-educated state public health employees in relation to their Ebola responder co-worker.

\section{The Study}

We developed a Web-based questionnaire (online Technical Appendix, http://wwwnc.cdc.gov/EID/article/ 21/11/15-0780-Techapp1.pdf) and distributed it through workplace email prior to the Ebola responder's return. The questionnaire provided background information

Author affiliations: New Hampshire Department of Health and Human Services, Concord, New Hampshire, USA (B.P. Chan, E.R. Daly, E.A. Talbot); Geisel School of Medicine at Dartmouth, Lebanon, New Hampshire, USA (E.A. Talbot)

DOI: http://dx.doi.org/10.3201/eid2111.150780 about the returning Ebola responder and asked 26 questions related to 13 hypothetical scenarios and 5 demographic questions. Respondents were asked to predict their reaction, depending on whether the Ebola responder had direct contact with Ebola patients while using appropriate personal protective equipment.

We grouped responses into dichotomous categories of "comfortable" and "uncomfortable" on the basis of the reported level of comfort or anticipated actions to avoid contact; data were analyzed with SAS v. 9.3 (SAS Institute Inc., Cary, NC, USA). We performed a univariate analysis using the Mantel-Haenszel $\chi^{2}$ and McNemar tests to evaluate response comparisons for demographic groups and paired response proportions, respectively. Two-tailed Fisher exact $\mathrm{p}$ values were used to assess statistical significance with $\mathrm{p}<0.05$ considered significant. We performed multivariate analyses using logistic regression to assess for associations between the multiple demographic variables and reported comfort level; odds ratios (ORs) were evaluated and considered significant if $\mathrm{p}<0.05$.

A total of 178 (71.2\%) of 250 staff members completed the questionnaire. Respondent characteristics are shown in Table 1; scenarios are listed in the first column of Table 2.

Even when the Ebola responder had had no contact with an EVD patient, 18.0\% of respondents were uncomfortable with the person returning to the workplace; $7.9 \%$ reported that they might not come to work if the Ebola responder was present. The proportion of respondents indicating discomfort generally increased in scenarios that described closer and/or more prolonged contact, from walking in the same hallway (14.7\%) to attending a holiday party at the Ebola responder's home (46.9\%). When the Ebola responder had direct contact with an EVD patient, the proportion of respondents uncomfortable with each scenario was significantly higher (Table 2), and the percentage of persons who were uncomfortable with a particular scenario increased by an average of $18.3 \%$.

In a univariate analysis, staff members who reported being uncomfortable with the return of an Ebola responder co-worker who had had no contact to EVD patients were 11 times more likely to work in noninfectious disease program areas $(O R=10.7, p=0.003)$. No staff person working in the infectious disease program reported discomfort with the Ebola responder returning to work, despite the fact that these employees would have the most contact with the Ebola responder. Because of this strong 
Table 1. Respondent characteristics for survey assessing workplace comfort levels with co-worker travel to an Ebolaaffected country

\begin{tabular}{lc}
\hline Characteristic & No. (\%) respondents, $\mathrm{n}=178^{*}$ \\
\hline Sex & $133(78.7)$ \\
$\mathrm{F}$ & $34(20.1)$ \\
$\mathrm{M}$ & $2(1.2)$ \\
Other & \\
\hline Age, $\mathrm{y} ;$ range 23-68, median 51 & $67(40.6)$ \\
$20-49$ & $98(59.4)$ \\
$50-69$ & $15(8.9)$ \\
\hline Education level & $19(11.2)$ \\
High school & $60(35.5)$ \\
Some college & $75(44.4)$ \\
Bachelor's degree & $38(22.8)$ \\
Graduate degree & $129(77.2)$ \\
\hline Program area & $26(15.1)$ \\
Infectious disease & \\
Other & \\
\hline Clinician & \\
\hline *Nonresponders for each demographic question were excluded from the \\
respective proportion calculations. Reponses were missing for program \\
area $(\mathrm{n}=11)$, sex $(\mathrm{n}=9)$, age $(\mathrm{n}=13)$, education level $(\mathrm{n}=9)$, and clinical \\
background $(\mathrm{n}=6)$.
\end{tabular}

association, we conducted a subgroup analysis of personnel working outside the infectious disease program, which showed that staff who reported being uncomfortable around the Ebola responder were 3 times more likely to have education below a bachelor's degree $(\mathrm{OR}=2.7, \mathrm{p}$ $=0.039$ ). In univariate or multivariate analyses, no other respondent characteristics were significantly associated with comfort or discomfort.

\section{Conclusions}

Without a doubt, Ebola virus is transmitted through direct contact with infectious body fluids from a symptomatic person (6-10), but this study suggests that even health department staff may not fully understand this concept. A substantial number of public health staff — with presumably excellent access to accurate EVD information-were uncomfortable with having an asymptomatic Ebola responder return to the workplace. Almost $15 \%$ of surveyed staff reported discomfort even walking in the same hallway as an Ebola responder who had had no contact with any EVD patients. Discomfort increased to $35.6 \%$ in scenarios describing closer proximity to or physical contact with the returning Ebola responder. Duration of contact also appeared to be a critical factor in perceived risk; more staff reported being uncomfortable sitting in a chair next to the Ebola responder (35.6\%) than with shaking the person's hand (29.6\%). This finding may reflect a residual, albeit incorrect, concern over airborne transmission.

Our survey did find that infectious disease staff demonstrated less discomfort. We surmise that these persons had better knowledge of EVD than noninfectious disease staff because they were directly involved in EVD response activities. When we excluded infectious disease staff, having an education level below a bachelor's degree was the only characteristic significantly associated with increased discomfort. These results are consistent with findings of several public polls: up to two thirds of persons believed that EVD spreads "easily" by multiple routes of transmission, with more than a third concerned that they or a family member could be exposed and get sick from Ebola virus; these beliefs were more common among those with less education (11-13).

The fear and concern expressed by public health staff are not unique to the United States. Fear and stigmatization in West Africa EVD-epidemic countries, fueled by lack of information and deeply engrained misperceptions, have hindered efforts to control the epidemic and have led to survivor discrimination. Likewise, although state policy allowed this Ebola responder to return to the workplace, the concern expressed by staff created an environment in which she felt she could not work, and she opted to telework.

\begin{tabular}{|c|c|c|c|c|c|}
\hline \multirow[b]{2}{*}{ Scenario } & \multirow{2}{*}{$\begin{array}{c}\text { No. paired } \\
\text { responses, } \\
n=178\end{array}$} & \multicolumn{2}{|c|}{ No. (\%) respondents } & \multirow[b]{2}{*}{$\begin{array}{l}\% \text { Change } \\
\text { (ratio) }\end{array}$} & \multirow[b]{2}{*}{$p$ value ${ }^{*}$} \\
\hline & & $\begin{array}{l}\text { Travel with contact } \\
\text { with Ebola patients }\end{array}$ & $\begin{array}{l}\text { Travel with no contact } \\
\text { with Ebola patients }\end{array}$ & & \\
\hline \multicolumn{6}{|l|}{ Uncomfortable with } \\
\hline Co-worker return to work & 178 & $76(42.7)$ & $32(18.0)$ & $--24.7(2.4)$ & $<0.001$ \\
\hline Walking in same hallway as co-worker & 177 & $57(32.2)$ & $26(14.7)$ & $-17.5(2.2)$ & $<0.001$ \\
\hline $\begin{array}{l}\text { Being in same room as co-worker for } \\
\text { meeting }\end{array}$ & 176 & $65(36.7)$ & $30(17.1)$ & $-19.6(2.1)$ & $<0.001$ \\
\hline Sitting in chair next to co-worker & 177 & $88(49.7)$ & $63(35.6)$ & $-14.1(1.4)$ & $<0.001$ \\
\hline Standing in line next to co-worker & 177 & $78(44.1)$ & $47(26.6)$ & $-17.5(1.7)$ & $<0.001$ \\
\hline Using same restroom as co-worker & 176 & $77(43.8)$ & $40(22.7)$ & $-21.1(1.9)$ & $<0.001$ \\
\hline Shaking hands with co-worker & 176 & $85(48.3)$ & $52(29.6)$ & $-18.7(1.6)$ & $<0.001$ \\
\hline Hugging co-worker & 175 & $87(49.7)$ & $59(33.7)$ & $-16.0(1.5)$ & $<0.001$ \\
\hline Riding in co-worker's car & 177 & $81(45.5)$ & $51(28.8)$ & $-16.7(1.6)$ & $<0.001$ \\
\hline Assisting co-worker if he/she fainted & 177 & $95(53.7)$ & $62(35.0)$ & $-18.7(1.5)$ & $<0.001$ \\
\hline Eating homemade food made by co-worker & 176 & $95(54.0)$ & 67 (37.9) & $-16.1(1.4)$ & $<0.001$ \\
\hline $\begin{array}{l}\text { Would consider not coming to work if co-worker } \\
\text { returned }\end{array}$ & 178 & $37(20.8)$ & $14(7.9)$ & $-12.9(2.6)$ & $<0.001$ \\
\hline Would not attend party at co-worker's home & 176 & $125(70.6)$ & $82(46.9)$ & $-23.7(1.5)$ & $<0.001$ \\
\hline
\end{tabular}

${ }^{*}$ McNemar's test for paired proportions. 
During this period, we conducted outreach to staff through staff meeting presentations, a small group question-andanswer session, and individual meetings to allow persons to ask questions and express concerns. When the monitoring period was over, the Ebola responder returned to work without incident.

Our survey has several limitations. First, scenarios cannot assess the source of discomfort evoked by interacting with a returning traveler; baseline discomfort from a handshake is predictably less than is assisting a co-worker who fainted, regardless of EVD risk. In addition, some responses appear inconsistent. Although riding in a car with an Ebola responder and sitting in an adjacent chair are not different in terms of proximity and contact, the responses differed substantially. Finally, the survey may have drawn attention to the Ebola responder and created concern that would not naturally have occurred if the Ebola responder had returned unannounced to the workplace.

Travelers returning from countries with widespread Ebola virus transmission can elicit strong reactions within their communities. Employers should consider taking active steps to address fears and concerns because workplace reactions and discrimination may have substantial effects on returning Ebola responders. Staff education remains the best approach to alleviating concerns and maintaining a functional workplace, while facilitating the needed humanitarian response to the historic EVD disaster.

Dr. Chan is a board-certified infectious disease and preventive medicine physician currently serving as state epidemiologist for the New Hampshire Department of Health and Human Services, Division of Public Health Services, Concord. His primary research interests include health care epidemiology, antimicrobial stewardship, and health care quality improvement.

\section{References}

1. Baize S, Pannetier D, Oestereich L, Rieger T, Koivogui L, Magassouba N, et al. Emergence of Zaire Ebola virus disease in Guinea. N Engl J Med. 2014;371:1418-25. http://dx.doi.org/ 10.1056/NEJMoa1404505

2. World Health Organization. Ebola response roadmap - situation report. 2015 Jun 24 [cited 2015 Jun 24]. http://www.who.int/csr/ disease/ebola/situation-reports/en/
3. Merino JG. Response to Ebola in the US: misinformation, fear, and new opportunities. BMJ. 2014;349:g6712. http://dx.doi.org/ 10.1136/bmj.g6712

4. Centers for Disease Control and Prevention. Interim U.S. guidance for monitoring and movement of persons with potential Ebola virus exposure. 2014 Dec 24 [cited 2015 Apr 23]. http://www.cdc.gov/ vhf/ebola/pdf/monitoring-and-movement.pdf

5. New Hampshire Division of Public Health Services. Interim policy summary for isolation of suspect Ebola patients and quarantine of persons potentially-exposed to Ebola virus. 2014 Nov 10 [cited 2015 Apr 23]. http://www.dhhs.state.nh.us/dphs/cdcs/ebola/ documents/isolationquarantine-interim.pdf

6. Baron RC, McCormick JB, Zubeir OA. Ebola virus disease in southern Sudan: hospital dissemination and intrafamilial spread. Bull World Health Organ. 1983;61:997-1003.

7. Dowell SF, Mukunu R, Ksiazek TG, Khan AS, Rollin PE, Peters CJ. Transmission of Ebola hemorrhagic fever: a study of risk factors in family members, Kikwit, Democratic Republic of the Congo, 1995. J Infect Dis. 1999;179(suppl 1):S87-91. http://dx.doi.org/10.1086/514284

8. Francesconi P, Yoti Z, Declich S, Onek PA, Fabiani M, Olango J, et al. Ebola hemorrhagic fever transmission and risk factors of contacts, Uganda. Emerg Infect Dis. 2003;9:1430-7. http://dx.doi.org/10.3201/eid0911.030339

9. Richards GA, Murphy S, Jobson R, Mer M, Zinman C, Taylor R, et al. Unexpected Ebola virus in a tertiary setting: clinical and epidemiologic aspects. Crit Care Med. 2000;28:240-4. http://dx.doi.org/10.1097/00003246-200001000-00041

10. Bausch DG, Towner JS, Dowell SF, Kaducu F, Lukwiya M, Sanchez A, et al. Assessment of the risk of Ebola virus transmission from bodily fluids and fomites. J Infect Dis. 2007;196:S142-7. http://dx.doi.org/10.1086/520545

11. Harvard School of Public Health. Poll finds many in U.S. lack knowledge about Ebola and its transmission [press release] 21 Aug 2014 [cited 2015 Apr 23]. http://www.hsph.harvard.edu/ news/press-releases/poll-finds-many-in-us-lack-knowledgeabout-ebola/

12. Pew Research Center. Ebola worries rise, but most are 'fairly' confident in government, hospitals to deal with disease. 21 Oct 2014 [cited 2015 Apr 23]. http://www.people-press.org/ files/2014/10/10-21-14-Ebola-Release.pdf

13. Harvard School of Public Health. Poll: most believe Ebola likely spread by multiple routes, including sneezing, coughing [press release]. 15 Oct 2014 [cited 2015 Apr 23]. http://www.hsph.harvard.edu/news/press-releases/ poll-finds-most-believe-ebola-spread-by-multiple-routes/

Author for correspondence: Benjamin P. Chan, Division of Public Health Services, New Hampshire Department of Health and Human Services, 29 Hazen Dr, Concord, NH 03301-6504, USA; email: benjamin.chan@dhhs.state.nh.us

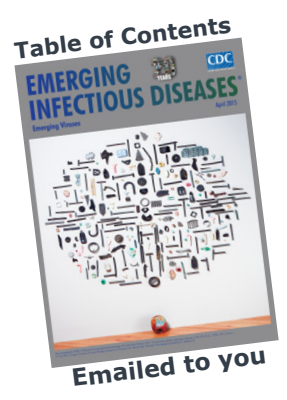

\section{GovDelivery}

Manage your email alerts so you only receive content of interest to you. Sign up for an Online Subscription:
wwwnc.cdc.gov/eid/subscribe.htm 